\title{
PENGARUH MOTIVASI KERJA GURU DAN KEPEMIMPINAN KEPALA SEKOLAH TERHADAP KEDISIPLINAN GURU SD DI TAMBAKROMO PATI
}

\author{
Roikatus Sa'diyah $^{1}$, Su'ad ${ }^{2}$, Gunawan Setiadi ${ }^{3}$ \\ 1,2,3 Universitas Muria Kudus, Kudus, Indonesia \\ ${ }^{1}$ roikatus@gmail.com, ${ }^{2}$ suad@umk.ac.id, ${ }^{3}$ gunsetia@gmail.com
}

\begin{abstract}
ABSTRAK
Tujuan penelitian ini adalah: 1) untuk menganalisis pengaruh motivasi kerja pada kedisiplinan guru SD di Kecamatan Tambakromo Kabupaten Pati. 2) menganalisis pengaruh data kepemimpinan kepala sekolah terhadap kedisiplinan guru SD di Kecamatan Tambakromo Kabupaten Pati. 3) menganalisis pengaruh motivasi kerja secara bersama-sama dengan kepemimpinan kepala sekolah terhadap kedisiplinan guru SD di Kecamatan Tambakromo Kabupaten Pati. Penelitian dilatarbelakangi oleh rendahnya motivasi kerja dan kedisiplinan guru serta kepemimpinan kepala sekolah. Permasalahan dalam penelitian ini adalah: 1) adakah pengaruh motivasi kerja guru terhadap kedisiplinan guru?, 2). adakah pengaruh kepemimpinan kepala sekolah terhadap kedisiplinan guru?, 3). adakah pengaruh motivasi kerja guru secara bersama-sama kepemimpinan kepala sekolah terhadap kedisiplinan guru?Pendekatan yang digunakan dalam penelitian ini adalah kuantitatif, Jenis penelitian korelasional atau mencari pengaruh antara variabel bebas motivasi kerja guru $\left(\mathrm{X}_{1}\right)$ dan kepemimpinan kepala sekolah $\left(\mathrm{X}_{2}\right)$, dengan variabel terikat: kedisiplinan guru (Y). Penelitian ini dilaksanakan pada bulan Juli sampai Agustus 2020 di 32 Sekolah Dasar Negeri di Kecamatan Tambakromo. Jumlah populasi 204 dan sampel 150 dipilih secara acak. Teknik pengumpulan data menggunakan angket. Dari olah data diketahui data berdistribusi normal, homogen, linier dan tidak multikolinier. Dari uji hipotesis ditemukan: 1). terdapat hubungan variabel $\mathrm{X}_{1}$ terhadap $\mathrm{X}_{2}$ dengan persamaan $\mathrm{Y}=36.851+0.345 \mathrm{X}_{1}$ diterima kebenarannya. Artinya setiap kenaikan satu satuan motivasi kerja akan menaikkan kedisiplinan guru sebesar 0.345 pada konstanta 36.851 , kekuatan korelasi sebesar 0.670. Besarnya kontribusi variabel $\mathrm{X}_{1}$ terhadap $\mathrm{Y}$ sebesar $55.2 \%, 2$ ). terdapat hubungan variabel $\mathrm{X}_{2}$ terhadap $\mathrm{Y}$ dengan persamaan $\mathrm{Y}$ $=36.851+0.395 \mathrm{X}_{2}$. Kekuatan korelasinya sebesar 0.680 dengan kontribusi $57.8 \%$, 3). terdapat hubungan positif antara motivasi kerja dan kepemimpinan kepala sekolah terhadap kedisiplinan guru yang dinyatakan dengan persamaan $\hat{\mathrm{Y}}=36.851+0.345 \mathrm{X}_{1}+0.395 \mathrm{X}_{2}$. Kekuatan korelasinya sebesar 0.707. Kontribusi variabel $\mathrm{X}_{1}$ dan $\mathrm{X}_{2}$ terhadap $\mathrm{Y}$ sebesar $49.9 \%$, sedangkan $50.1 \%$ dipengaruhi oleh faktor yang lain.
\end{abstract}

Kata Kunci: motivasi kerja, kepemimpinan, kedisiplinan, penelitian korelasi

\section{THE INFLUENCE OF TEACHERS' WORK MOTIVATION AND THE PRINCIPALS' LEADERSHIP TOWARD TEACHERS' DISCIPLINE IN TAMBAKROMO PATI}

\begin{abstract}
The objectives of this study were: 1) Analyzing the effect of work motivation on the discipline of elementary school teachers in Kecamatan Tambakromo, Kabupaten Pati, 2) Analyzing the effect of principals' leadership on the discipline of elementary school teachers in Kecamatan Tambakromo, Kabupaten Pati, 3) Analyzing the effect of work motivation and the principals' leadership on the discipline of elementary school teachers in Kecamatan Tambakromo, Kabupaten Pati. This research was quantitative research which was classified as correlational research. This research is aiming to seek the influence of teacher work motivation (independent variables, $X_{1}$ ) and principals' leadership (independent variables, $X_{2}$ ) towards the teachers' discipline (the dependent variable, Y). The research was conducted from July to August 2020 at 32 public elementary schools throughout Kecamatan Tambakromo. The total population was 204 people, and 150 samples were randomly selected. The data were collected by questionnaires. It was found that the data were normally distributed, homogeneous, linear, and not multicollinear. The hypothesis test obtained: 1) there was a relationship between the variable $X_{1}$ and $X_{2}$ with the equation of $Y=36.851+0.345 X_{1}$, so the hypothesis was accepted. It indicated that every increase of one unit of work motivation increased teachers' discipline by 0.345 at a constant of 36.851 , and the strength of the correlation was 0.670. Then, the percentage of the contribution of the variable $X_{1}$ to $Y$ was $55.2 \%$; 2) there was a relationship between the variable $X_{2}$ and $Y$ with the equation of $Y=36.851+0.395 X_{2}$ The score of the correlation was 0.680 with a contribution of $57.8 \%$; 3) there was a positive relationship between work motivation and principals' leadership on teachers' discipline which was stated by the equation $\hat{Y}=36.851+0.345 X_{1}+0.395 X_{2}$. The correlation score was 0.707. Finally, the contribution of variables $X_{1}$ and $X_{2}$ to $Y$ was $49.9 \%$, while $50.1 \%$ was influenced by other factors.
\end{abstract}

Keywords: work motivation, leadership, discipline, correlation research

\begin{tabular}{|c|c|c|}
\hline Submitted & Accepted & Published \\
\hline 01 Maret 2021 & 05 September 2021 & 23 November 2021 \\
\hline
\end{tabular}

\begin{tabular}{|l|c|r|}
\hline Citation & $:$ & $\begin{array}{r}\text { Sa'diyah, R., Su'ad, S., \& Setiadi, G. (2021). Pengaruh Motivasi Kerja Guru dan Kepemimpinan Kepala Sekolah Terhadap } \\
\text { Kedisiplinan Guru SD di Tambakromo Pati. Jurnal PAJAR (Pendidikan dan Pengajaran), 5(6), 1559-1565. DOI } \\
: \text { http://dx.doi.org/10.33578/pjr.v5i6.8344. }\end{array}$ \\
\hline
\end{tabular}




\section{PENDAHULUAN}

Rendahnya kedisiplinan guru Sekolah Dasar di Kecamatan Tambakromo Kabupaten Pati merupakan masalah yang serius. Hal itu karena beberapa factor, diduga karena pengaruh motivasi kerja dan kepemimpinan kepala sekolah, Komponen yang sangat menentukan dalam meningkatkan sumber daya manusia melalui proses pendidikan adalah guru. Guru memegang peranan strategis dalam upaya membentuk watak bangsa melalui pengembangan kepribadian dan nilai-nilai yang diinginkan. Dari dimensi tersebut peranan guru sulit digantikan dengan yang lain. Kehadiran guru di kelas tetap dominan sekalipun teknologi pembelajaran berkembang sangat cepat.

Berdasarkan pengamatan selama periode Juli - Agustus 2020 di beberapa sekolah dasar di wilayah Kecamatan Tambakromo ditemukan beberapa indikasi ketidak disiplinan guru diantaranya: 1). karena keterlambatan hadir guru tidak bisa menyambut kedatangan siswa dengan cara bersalaman ketika siswa masuk kelas ,2). beberapa guru meninggalkan ruang kelas setelah memberikan tugas kepada siswanya, 3). waktu istirahat yang lebih lama dari jadwal yang ditentukan, 4). guru tidak mengisi daftar hadir secara rutin setiap hari, 5). guru tidak membuat administrasi pembelajaran tepat waktu, 6). guru pulang lebih awal dari jam kerja yang telah ditentukan.

Dalam kenyataan kepala sekolah belum banyak memahami tugas pokok dan fungsinya. Hal ini disebabkan oleh proses pengangkatan kepala sekolah yang tidak berdasar pada kompetensi. Beberepa permasalahan yang muncul pada kepala sekolah diantaranya: 1). Kekurangmampuan kepala sekolah dalam penggunaan peralatan komputer, 2). pengangkatan kepala sekolah berdasarkan senioritas bukan berdasarkan kemampuan, 3). kepala sekolah melimpahkan tugasnya kepada guru tanpa memberikan penjelasan, 4). kepala sekolah jarang melakukan supervisi kelas, 5) kepala sekolah kurang mampu memberdayakan guru yang memiliki potensi lebih dari guru-guru yang lainya, 6). kurang mampu menyusun program yang berkaitan dengan kebijakan pendidikan.

\section{KAJIAN TEORETIS \\ Hakikat Kedisiplinan Guru}

Berbagai pengertian mengenai disiplin kerja yaitu : Lemhanas (1997:12) memberikan batasan, disiplin adalah kepatuhan untuk menghormati dan melaksanakan suatu system yang mengharuskan orang tunduk pada keputusan, perintah atau peraturan yang berlaku.

Pengertiaan kedisiplinan menurut Hasibuan (2012:193) adalah sebagai berikut : "kedisiplinan adalah kesadaran dan kesediaan seseorang mentaati semua peraturan organisasi dan norma-norma sosial yang berlaku. Kesadaran adalaah sikap seseorang yang secara sukarela mentaati semua peraturan dan sabar akan tugas dan tanggung jawabnya, jadi dia akan mematuhi/mengerjakan semua tugasnya dengan baik, bukan atas paksaan. Kesediaan adalah suatu sikap, tingkah laku dan perbuatan seseorang yang sesuai dengan peraturan organisasi baik yang tertulis maupun tidak."

\section{Motivasi Kerja Guru}

Soedarmono (2010:34) mendefinisikan motivasi sebagai suatu tenaga atau faktor yang terdapat di dalam diri manusia yang menimbulkan, mengarahkan dan mengorganisasikan tingkah laku. Sementara Robbins (2008:222), memberikan batasan , motivasi adalah kesediaan untuk mengeluarkan tingkat upaya yang tinggi untuk tujuan organisasi yang dikondisikan oleh kemampuan upaya itu dalam memenuhi beberapa kebutuhan individual. Kebutuhan terjadi apabila tidak ada keseimbangan antara apa yang dimiliki dan apa yang diharapkan. Dorongan merupakan kekuatan mental yang berorientasi pada pemenuhan harapan dan pencapaian tujuan. Dan tujuan adalah sasaran atau hal yang ingin dacapai oleh seseorang individu.

\section{Kepemimpinan Kepala Sekolah}

Sekolah merupakan salah satu bentuk organisasi pendidikan. Kepala Sekolah merupakan pemimpin pendidikan di sekolah. Hal ini sesuai dengan pendapat Good dalam Soegito (2010:41) kepemimpinan merupakan suatu kemampuan dan kesiapan seseorang untuk mempengaruhi, 
membimbing dan mengarahkan atau mengelola orang lain agar mau berbuat sesuatu demi tercapainya tujuan bersama. Masih dalam Sugito, (2010:41) Banchard mengatakan , kepemimpinan tidak lain adalah proses mempengaruhi kegiatan individu atau kelompok dalam usaha untuk mencapai tujuan dalam situasi tertentu. Kepemimpinan pendidikan adalah kemampuan dan kesiapan untuk dapat menggerakkan dan membina para pendidik atau aparatur pendidikan, sehingga mereka mau melaksanakan tugas-tugas pendidikan secara efektif dan efisien dalam rangka mencapai tujuan pendidikan (Sumarsono.2012:2339). Selanjutnya menurut Chemers dalam Hoy dan Miskel (2014:635) mengatakan , kepemimpinan adalah proses pengaruh sosial tatkala seseorang mampu merangsang pertolongan dan dukungan orang-orang lain demi mewujudkan tugas bersama.Sedangkan Mukhtar (2009:76) mengatakan kepemimpinan merupakan suatu proses mempengaruhi yang dilakukan oleh seseorang dalam mengelola anggota kelompoknya untuk mencapai tujuan organisasi.

\section{METODE PENELITIAN \\ Rancangan Penelitian}

Rancangan penelitian yang digunakan dalam penelitian ini adalah deskriptif korelasional dengan desain hubungan antar variabel sebagaimana tercermin dalam gambar diagram sebagai berikut :
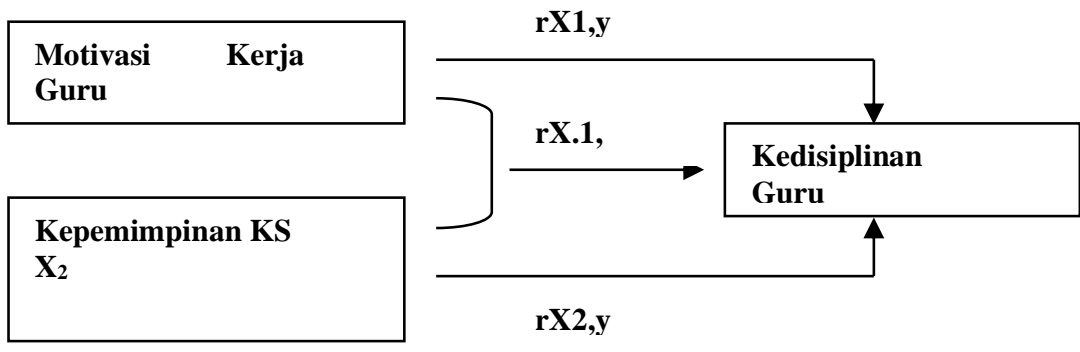

\section{Gambar 1. Desain Penelitian}

Hubungan X2 dengan Y, artinya kepemimpinan kepala sekolah memberi kontribusi terhadap kedisiplinan guru, jika kepemimpinan kepala sekolah efektif maka kedisiplinan guru tersebut juga tinggi.

Sedangkan paradigma simultan menggambarkan hubungan secara bersama-sama antara kedua variabel bebas ( X1, dan X2) terhadap variabel terikat $(\mathrm{Y})$ yang berarti bahwa motivasi kerja guru dan kepemimpinan kepala sekolah secara bersama-sama memberi kontribusi terhadap kedisiplinan guru, guru yang motivasinya tinggi dan kepemimpinan Kepala Sekolah efektif maka guru tersebut memiliki tingkat kedisiplinan yang tinggi.

\section{Populasi Sampel dan Sampling Populasi}

Populasi adalah wilayah generalisasi yang terdiri atas: objek atau subjek yang mempunyai kuantitas dan karakteristik tertentu yang ditetapkan oleh peneliti untuk dipelajari dan kemudian ditarik kesimpulannya, (Sugiyono.2009:80) Populasi adalah keseluruhan dari sasaran penelitian (Sugeng 2006:70). Populasi adalah keseluruhan komponen atau kelompok yang memiliki satu atau lebih karakteristik tertentu yang sama dari sampel yang diambil. Atas dasar pendapat tersebut peneliti dapat menarik kesimpulan bahwa populasi adalah sejumlah penduduk atau individu yang dijadikan objek penelitian ilmiah. Anggota populasi paling tidak memiliki satu sifat yang sama.

Yang menjadi populasi dalam penelitian ini adalah seluruh guru kelas I s/d kelas VI SD Negeri di Kecamatan Tambakromo tahun pelajaran 2020/2021 yang berstatus PNS maupun GTT 
sebanyak 204 orang dari 32 sekolah yang tersebar di 18 desa.

\section{Sampel dan Sampling}

Sampel adalah bagian dari jumlah dan karakteristik yang dimiliki oleh populasi (Sugiyono. 2010:62). Sementara Sudjana (2005:161) memberikan batasan sampel adalah bagian yang diambil dari poulasi dengan menggunakan cara-cara tertentu. Sampel adalah sebagian dari jumlah populasi yang memiliki karakteristik dari populasi tersebut. Sampel yang diambil haruslah representatif, artinya sampel harus mencerminkan dan memiliki sifat populasi (Azwar, 2010).

Untuk menentukan ukuran sampel dari populasi, peneliti menggunakan rumus Slovin, 1960( dalam Sevilla, consuelo. Dkk, 1993) sebagai berikut:

$$
n=\frac{N}{1+N e^{2}}
$$

Jumlah sampel minimal adalah sebanyak 68 orang. Dalam penelitian ini sampel yang digunakan adalah 68 orang. Di Kecamatan Tambakromo ada 3 dabin maka jumlah sampel dari masing masing dabin sama, yaitu 23 guru per dabin..

\section{Teknik Pengumpulan Data}

Dalam penelitian ini teknik pengumpulan data yang penulis gunakan adalah angket. Riduwan (2014: 52) mengemukakan bahwa, angket adalah daftar pertanyaan yang diberikan kepada orang yang bersedia memberikan respons sesuai dengan permintaan pengguna.

Dalam penelitian ini, angket disusun menggunakan skala Likert yang alternatif jawabannya bergerak diantara 5 skala, yaitu : Sangat setuju (SS) bila pernyataan itemnya positif berarti bobot penilaiannya 5. Setuju (S) bila pernyataan itemnya positif berarti bobot penilainnya 4. Ragu-ragu (R) bobot penilaiannya 3. Tidak Setuju (TS) bobot penilaiannya 2, dan Sangat Tidak Setuju (STS) bobot nilainya 1. Sebaliknya bila pernyataan itemnya negatif, SS bobot penilaiannya $1, \mathrm{~S}$ bobot penilaiannya $2, \mathrm{R}$ bobot penilaiannya 3 , TS bobot penilaiannya 4 dan STS bobot nilainya 5 .

\section{Instrumen Penelitian}

Kisi-kisi instrumen setiap variabel penelitian dikelompokan menjadi beberapa subvariabel, selanjutnya subvariabel disebarkan ke dalam deskripsi indikator sehingga data/informasi yang terjaring akan lebih terarah kepada tujuan penelitian. Kisi-kisi instrumen variabel dituangkan ke dalam table.

\section{Variabel Kedisiplinan Guru}

Variabel kedisiplinan guru dikembangkan dari sub variabel yang terdiri dari pengertian disiplin, faktor-faktor yang mempengaruhi disipin dan macam-macam disiplin. Dari ketiga subvariabel tersebut dikembangkan menjadi beberapa indikator.

\section{Variabel Motivasi Kerja Guru}

Instrumen penelitian untuk variabel motivasi kerja dari uraian tentang pengertian motivasi, teori dan faktor-faktor yang menpengaruhi motivasi kerja guru. Adapun indikator yang digunakan dalam penelitian ini adalah: 1). adanya kebutuhan dan pengakuan berprestasi, 2). kesempatan untuk berafiliasi, dan kekuasaan, 3). kenyamanan kerja, perlakuan wajar dan partisipasi, 4). adanya gaji, upah dan tunjangan, 5). berminat terhadap tugas, berkarya dan bertanggung jawab, dan 6). adanya inisiatif dan kreatifitas

\section{Variabel Kepemimpinan Akademik Kepala Sekolah}

Merujuk pada beberapa pengertian tentang kepemimpinan akademik, gaya kepemimpinan dan tujuan kepemimpinan akademik dapat disimpulkan bahwa ada 5 indikator dalam penyusunan angket penelitian yaitu: 1). kemampuan mempengaruhi bawahan dan menatik simpati atau dukungan dalam mencapai tujuan , 2). Mampu mengorganisasi, mengadministrasi, melakukan supervisi dan menjadi teladan, 3). mencipta iklim kerja dengan manajemen terbuka, memberdayakan bawahan dan meningkatkan prestasi, 4).adanya motivasi belajar, kreatifitas dan inovasi, 5). adanya jiwa kewirausahaan, dan kesadaran untuk belajar sepanjang hayat. 


\section{Teknik Analisis Data \\ Analisis Diskriptif}

Diskripsi responden meliputi pendidikan, jenis kelamin, status kepegawaian dan golongan. Responden dalam penelitian ini adalah guru yang bekerja di SD Negeri Kecamatan Tambakromo sebanyak 204 orang. Untuk penentuan responden berdasarkan status kepegawaiannya, yaitu yang berstatus PNS dan non PNS.

\section{Uji Persyaratan}

Uji normalitas dilakukan untuk mengetahui apakah data suatu variabel penelitian mengikuti distribusi data yang normal atau tidak. Data yang berdistribusi normal berarti mempunyai sebaran yang normal pula. Tingkat kenormalan data sangat penting, karena dengan data yang berdistribusi normal, maka data tersebut dianggap dapat mewakili populasi. Dalam penelitian ini uji normalitas data menggunakan uji One Sample Kolmogorof-Smirnov test, dengan menggunakan fasilitas program SPSS for wndows release 16.

\section{Uji Hipotesis Penelitian}

Analisis regresi linier sederhana didasarkan pada hubungan fungsional ataupun kausal satu variabel independen dengan satu variabel dependen. Dalam penelitian ini analisis regresi linier sederhana digunakan untuk menguji hipotesis tunggal antara satu variabel independen dan satu variabel dependen. Jadi ada dua macam hipotesis yang akan di uji yaitu Hipotesis 1: pengaruh motivasi kerja guru $\left(\mathrm{X}_{1}\right)$ terhadap kedisiplinan guru $(\mathrm{Y})$ dan Hipotesis 2: pengaruh kepemimpinan akademik kepala sekolah $\left(\mathrm{X}_{2}\right)$ terhadap kedisiplinan guru (Y).

Untuk menguji hipotesis digunakan rumus persamaan analisis regresi linier sederhana yaitu:

$$
\hat{\mathrm{Y}}=\mathrm{a}+\mathrm{bX}
$$

Uji t atau uji koefisien regresi sederhana digunakan untuk menguji apakah variabel independen secara sendiri-sendiri (parsial) berpengaruh terhadap variabel dependen.

Analisis regresi ganda digunakan oleh peneliti, bila peneliti bermaksud meramalkan bagaimana keadaan (naik turunnya) variabel dependen (kriterium), bila dua atau lebih variabel independen sebagai prediktor dimanipulasi (dinaik-turunkan nilainya).

Untuk menguji hipotesis digunakan rumus persamaan analisis regresi linier berganda yaitu:

$$
\hat{\mathrm{Y}}=\mathrm{a}+\mathrm{b}_{1} \mathrm{X}_{1}+\mathrm{b}_{2} \mathrm{X}_{2}
$$

Uji $F$ atau uji koefisien regresi secara simultan digunakan untuk menguji apakah variabel independen secara bersama-sama (simultan) berpengaruh terhadap variabel dependen.

Analisis korelasi product moment digunakan untuk mengetahui hubungan antara satu variabel independen dengan variabel dependen secara linier. Data yang digunakan berskala interval atau rasio.

Analisis Adjusted $\mathrm{R}^{2}$ atau analisis koefisien determinasi dilakukan untuk mengetahui besarnya kontribusi sumbangan variabel motivasi kerja guru terhadap kedisiplinan guru dan variabel kepemimpinan kepala sekolah terhadap kedisiplinan guru.

\section{HASIL DAN PEMBAHASAN}

Dari hasil analisis statistik di atas dapat diketahui mean variabel motivasi kerja guru 91 termasuk dalam interval kelas 90 - 98 yang kategorinya adalah sedang. Jadi dapat disimpulkan bahwa motivasi guru termasuk kategori sedang.

Untuk kemampuan mempengaruhi pengikut/bawahan dan menarik dukungan dan kemampu mengorganisasi, mengadministrasi, melakukan supervisi dan menjadi teladan, masuk dalam kategori sangat rendah. Artinya kemampuan kepala sekolah yang berhubungan dengan kompetensi tersebut perlu untuk ditingkatkan. Untuk indikator mencipta manajemen terbuka, memberdayakan bawahan dan meningkatkan prestasi serta indikator adanya jiwa kewirausahaan, dan kesadaran untuk belajar sepanjang hayat masuk kategori sedang.

Dari hasil analisis statistik di atas dapat diketahui mean variabel kedisiplinan guru 99 termasuk dalam interval kelas 99 - 107 kategori sedang. Jadi dapat disimpulkan bahwa kedisiplinan guru termasuk kategori sedang. 
Pembahasan

\section{Pengaruh Motivasi Kerja terhadap Kedisiplinan Guru}

Besarnya kontribusi antara variabel motivasi kerja terhadap variabel kedisiplinan guru adalah sebesar 0.552 atau sebesar $55.2 \%$. Hasil temuan ini membuktikan adanya pengaruh yang positif dan signifikan dari motivasi kerja terhadap variabel kedisiplinan guru, motivasi kerja memiliki peran penting dalam meningkatkan kedisiplinan guru.

\section{Pengaruh Kepemimpinan Akademik Kepala Sekolah terhadap Kedisiplinan Guru}

Besarnya kontribusi antara variabel kepemimpinan kepala sekolah dan kedisiplinan guru adalah sebesar 0.578 atau sebesar $57.8 \%$. Berdasarkan data tersebut, maka hasil penelitian ini menunjukkan bahwa terdapat pengaruh positif dan signifikan antara kepemimpinan kepala sekolah dengan kedisiplinan guru- guru SD Negeri di Korwil Pendidikan Kecamatan Tambakromo Kabupaten Pati.

Kepemimpinan akademik kepala sekolah yang baik akan mempengaruhi kedisiplinan guru dan keberhasilan guru dalam mengajar. Oleh karena itu kepala sekolah harus mampu untuk melaksanakan kepemimpinan akademik yang baik serta mampu membangkitkan semangat para guru di sekolah masing-masing.

\section{Pengaruh Motivasi Kerja dan Kepemimpinan Akademik Kepala Sekolah terhadap Kedisiplinan Guru}

Besarnya kontribusi antara motivasi kerja dan kepemimpinan kepala sekolah terhadap kedisiplian guru sebesar 0.499 atau sebesar 49.9\%, sedangkan $50.1 \%$ dipengaruhi oleh faktor yang lain. Jadi korelasi antara motivasi kerja dan kepemimpinan kepala sekolah secara bersamasama terhadap kedisiplinan guru signifikan, artinya semakin tinggi motivasi kerja dan kepemimpinan kepala sekolah, semakin tinggi pula tingkat kedisiplinan guru.

Secara garis besar hasil temuan penelitian ini terdapat pengaruh positif dan signifikan antara motivasi kerja dan kepemimpinan kepala sekolah terhadap kedisiplinan guru SD Negeri di Kecamatan Tambakromo Kabupaten Pati.
Motivasi kerja memberikan kontribusi sebesar $55.2 \%$ terhadap kedisiplinan guru dan kepemimpinan kepala sekolah memberikan kontribusi sebesar $57.8 \%$ terhadap kedisiplinan guru SD Negeri di Kecamatan Tambakromo Kabupaten Pati. Sedangkan motivasi kerja dan kepemimpinan kepala sekolah secara bersamasama memberikan kontribusi sebesar 49.9\% terhadap kedisiplinan guru SD Negeri di Kecamatan Tambakromo Kabupaten Pati.

\section{SIMPULAN DAN REKOMENDASI}

Pengaruh motivasi kerja guru terhadap kedisiplinan guru SD Negeri di Kecamatan Tambakromo, Kabupaten Pati sebesar 55.2\%. Semakin tinggi motivasi kerja semakin tinggi pula kedisiplinan guru. Adapun pengaruh kepemimpinan kepala sekolah terhadap kedisiplinan guru ssbesar $57.8 \%$. Semakin tinggi keefektifan kepemimpinan kepala sekolah semakin tinggi pula kedisiplinan guru. Dan pengaruh antara motivasi kerja dan kepemimpinan kepala sekolah secara bersamasama terhadap kedisiplinan guru sebesar $49.9 \%$. Semakin tinggi motivasi kerja guru dan kepemimpinan kepala sekolah makin tinggi pula tingkat kedisiplinan guru.

Kepada para guru diharuskan untuk meningkatkan motivasi kerjanya karena dengan motivasi kerja akan meningkatkan kedisiplinan dan dengan kedisiplinan akan meningkatkan prestasi kerja utamanya adalah raihan prestasi dari anak didik. Dalam rangka meningkatkan motivasi kerja kepala sekolah dapat memberikan penghargaan kepada para guru yang mempunyai prestasi yang menonjol dari guru yang lain. Pemenuhan kebutuhan guru juga perlu diperhatikan.

\section{DAFTAR PUSTAKA}

Amalda, N, \& Prasojo, L. D. (2018). Pengaruh Motivasi Kerja Guru, Disiplin Kerja Guru, dan Kedisiplinan Siswa Terhadap Prestasi Belajar Siswa. Tersedia di http://journal.uny.ac.id/index.php/jamp. Diunduh tanggal 10 Agustus 2020 Pukul 10.25 .

Amoah, S. A., \& Francis, O. L. (2015). Managing School Discipline: The Students' And 
Jurnal PAJAR (Pendidikan dan Pengajaran)

Volume 5 Nomor 6 November | ISSN Cetak : 2580 - 8435| | ISSN Online : 2614 - 1337

DOI : http://dx.doi.org/10.33578/pjr.v5i6.8344

Teachers' Perception On Disciplinary Strategies. (British Journal of Psychology Research). Tersedia di www.eajournals.org. Diunduh tanggal 13 Agustus 2020 Pukul 10.33.

Arikunto, S. (1993). Organisasi dan Administrasi Pendidikan Teknologi dan Kejuruan. Jakarta: P2LPTK.

Budiawati, J. (2017). Iklim, Kepuasan, Dan Motivasi Kerja Guru Di Sekolah Dasar Bpk Penabur. Tersedia di ejournal.upi.edu. Diunduh tanggal 11 Agustus 2020 Pukul 09.55 .

Britt, M. (2016). Classroom Management: what does research tell us?( European Educational Research Journal) Tersedia di www.wwwords.eu. Diunduh tanggal 13 Agustus 2020 Pukul 10.54.

Djafar, H., \& Nurhafizah. (2018). Pengaruh Motivasi Kepala Sekolah Terhadap Kinerja Guru Dan Pegawai Di Smk Muhammadiyah 3 Makassar. Tersedia di journal.uin-alaudin.ac.id. Diunduh tanggal 23 Juni 2020 Pukul 22.30.

Gusti, M. M. (2012). "Pengaruh Kedisiplinan Motivasi Kerja dan Persepsi Guru Tentang Kepemimpinan Kepala Sekolah Terhadap Kinerja Guru SMKN 1 Purworejo Pascasertifikasi" Tesis. Fakultas teknik Universitas Negeri Yogyakarta.

Handoko, T. H. (2014). Manajemen Personalia dan Sumber Daya Manusia. Yogyakarta : BPFE.

Jumriah, H. A., \& Darwis, M. (2016). Disiplin Kerja Guru Dalam Melaksanakan Tugas Pembelajaran Di Sekolah Menengah Kejuruan Negeri 1 Barru. Tersedia di ojs.journal.unm.ac.id. Diunduh tanggal 10 Agustus 2020 Pukul 10.10.

Khun-inkeeree, H., Masturah, A., \& Kamaruddin. (2019). The Relationship of Primary School Principals' Leadership Practice on Teachers' Commitment. (Indian Journal of Science and Technology) Tersedia di www.researchgate.net. Diunduh tanggal 3 Juni 2020 Pukul 20.40.

Lee, H., \& Mao-neng, F. L. (2015). Principal Leadership and Its Link to the Development of a School's Teacher
Culture and Teaching Effectiveness: A Case Study of an Award-Winning Teaching Team at an Elementary School.( Inter Journal of Education Polis and Leadership). Tersedia di file.eric.ed.gov. Diunduh tanggal 3 Juni 2020 Pukul 20.11.

Lemhanas. (1997). Disiplin Nasional, Jakarta : Balai Pustaka.

Liani, A., Jamhur., \& Suradji, P. (2014). Kedisiplinan Guru Pada Sekolah Dasar Negeri 004 Tanjungpinang Barat. Tersedia di jurnal.umrah.ac.id. Diunduh tanggal 11 Agustus 2020 Pukul 09.30.

Sugito, A. T. (2010). Kepemimpinan Manajemen Berbasis Sekolah. Semarang :Unnes Press. 